\title{
The resistance of the four European worlds of welfare from the birth of the euro
}

\author{
A resistência dos quatro mundos europeus do \\ bem-estar desde o nascimento do euro
}

ANTÓN LOSADA*

CRISTINA ARES**

RESUMO: Este artigo compara as preferências parlamentares sobre gastos com bem-estar na Áustria, Bélgica, Dinamarca, Finlândia, França, Alemanha, Grécia, Irlanda, Itália, Luxemburgo, Holanda, Portugal, Suécia e Reino Unido entre 1996 e 2013. A análise concentra-se na relação entre o tipo de regime de bem-estar e a oferta programática sobre o volume de gastos sociais. Foram calculados dois índices: gasto social e contenção social. Ao sair da recessão, detecta-se uma concepção cada vez mais homogênea das políticas sociais como subordinadas às políticas econômicas; a convergência ocorreu dentro de cada um dos mundos de bem-estar, mantendo a variação entre eles encontrada antes da Crise.

PALAVRAS-CHAVE: Preferências políticas; Projeto Manifesto; gasto social; contenção social; regimes de bem-estar; reformas do estado de bem-estar.

ABSTRACT: This article compares parliamentary preferences on welfare expenditure in Austria, Belgium, Denmark, Finland, France, Germany, Greece, Ireland, Italy, Luxembourg, Netherlands, Portugal, Sweden, and the United Kingdom between 1996 and 2013. The analysis is focused on the relationship between the type of welfare regime and the programmatic offer on the volume of social spending. Two indexes were calculated: social spending and social retrenchment. Upon emergence from the recession, an increasingly homogeneous conception is detected of social policies as being subordinated to economic policies; convergence has occurred within each of the worlds of welfare, maintaining the variation among them found prior to the Crisis.

KEYWORDS: Political preferences; Manifesto Project; social spending; social retrenchment; welfare regimes; welfare state reforms.

JEL Classification: H; H5; H51; H52; H53; H55.

\footnotetext{
* Associate Professor of Political Science, University of Santiago de Compostela, Santiago de Compostela/Coruña, Spain. E-mail: antonio.losada@usc.es. Orcid: https://orcid.org/0000-0002-6763-541X.

* Senior Lecturer of Political Science, University of Santiago de Compostela, Santiago de Compostela/ Coruña, Spain. E-mail: cristina.ares@usc.es. Orcid: https://orcid.org/0000-0002-2278-629X. Submitted: 12/June/2019; Approved: 8/June 2020.
} 


\section{INTRODUCTION}

The reform of the welfare state (WS) has held a central position in the political agenda of European countries since the conservative revolution led by Margaret Thatcher in the 1980s. At the start of the 21st century, following the period of economic expansion that accompanied the implementation of the euro, the Great Recession has once again accelerated the pressures for wide-ranging reforms of welfare policies as part of a supposedly inevitable response to the sovereign debt crisis and the fiscal problems of large public expenditure programs, such as pensions and healthcare. This article attempts to reintroduce politics into the study of welfare policies on the continent, through the study of the evolution of the parliamentary preferences with regard to the volume of social spending in the European Union (EU)-15 (Austria, Belgium, Denmark, Finland, France, Germany, Greece, Ireland, Italy, Luxembourg, Netherlands, Portugal, Sweden and the United Kingdom), and their connection to the different institutionalized models of welfare in this region.

The following working hypothesis is tested: different regimes, different political offers. The different welfare regimes induce different dynamics in the proposals of the main parties with regard to welfare expenditure, which triggers a convergence in the parliamentary position on the volume of social spending among the countries of the same regime, as well as the maintenance of diversity among regimes. To test this hypothesis, we created two indexes, "social spending" and "social retrenchment," as described in the second section.

In addition to the empirical analysis itself, in the third section, we provide a comparison of the reform policies developed in the different welfare states. Reviewing data, institutional documents and secondary reference sources, we have tried to determine whether different strategies coexist, or whether they are particular to each of the regimes. In fact, we have managed to demonstrate how the different welfare regimes have had an influence on the content of policies: different regimes, different responses.

Finally, in the conclusions, we highlight the resistance of the concept of the welfare regime and the persistent impact of institutional variables on the parliamentary positions regarding the volume of social spending.

\section{METHOD. INDEXES ON SOCIAL SPENDING AND SOCIAL RETRENCHMENT}

In order to examine the eventual convergence in the position of the national parliaments regarding social spending in Europe, this work studies the countries of the EU-15 for the following two reasons: the Member States that joined the European Union later (after 2004, mostly from Eastern Europe) present welfare models that are too different from those above to be included in this comparative study; likewise, it is necessary to manage a sufficient period of EU membership in order to assess the impact of the Great Recession. 
For these reasons, the study begins in 1996. It was decided to end it in 2013, not extending the study any further over time, due to the lack of availability of comparative data for the next electoral cycle on the preferences of the parties with representation in all EU-15 parliaments with regard to social expenditure.

The Manifesto Project (Volkens et al., 2013) database is used; the data processed were thus generated through the quantitative analysis of the political manifestos. In particular, the following four variables were considered:

"Welfare State Expansion" (504). Favorable mentions of the need to introduce, maintain or expand any public social service or social security scheme. This includes, for example, government funding of health care, childcare, elder care and pensions, as well as social housing. This category excludes education.

"Welfare State Limitation" (505). Limiting state expenditures on social services or social security. Favorable mentions of the social subsidiary principle (i.e., private care over state care).

"Education Expansion" (506). The need to expand and/or improve educational provisions at all levels. This excludes technical training, which is coded under 411.

"Education Limitation" (507). Limiting state expenditure on education. This may include the introduction or expansion of student fees at all educational levels and the increase in the number of private schools.

These are used to calculate two indexes of our own creation to measure the position of the national parliaments on the expansion or reduction of social spending in each legislature. The support is measured for the expansion of the financing of all welfare policies, including education (social spending), as well as the declared defense of cuts in public spending destined for these policies (social retrenchment).

For the calculations, first the position of each party is obtained that was represented in the parliament in each legislature; next it is weighted by the number of members of parliament. The formulas are as follows:

"Social spending": $(504+506)-(505+507)$, weighted by the number of seats.

"Social retrenchment": $(505+507)$, also weighted by the number of seats.

\section{WELFARE REGIMES IN EUROPE AND REFORMS}

\section{OF THE WELFARE STATES. POLICIES}

During the process of expansion and consolidation of the WS throughout the 20th century, different forms of institutional organization have coexisted, demonstrating important divergences among countries. The search for models that would make it possible to systematize such differences has represented one of the driving 
forces behind the study of the WS, as has the analysis of their validity to explain their evolution, politics and policies in the different models and countries. Rigorously categorizing its different types has been a constant in the analysis of the WS, ever since in his classical work Titmuss (1958) initially identified three types, based on their functionality: the residual welfare state, subordinated to the failures of the family or market, the welfare state of industrial development, subordinated to the market and economic growth and the redistributive or institutional welfare state, with social services as a necessary state function.

The best-known, most widespread and influential model was provided by Esping-Andersen (1990 and 1999), through his three famous "worlds" of welfare. In his model, Esping-Andersen uses the terms "regime" and "world" instead of "state" to clarify that they do not refer to specific states or countries, since all countries with welfare systems include elements of all three regimes or worlds, although he does point out those countries where he considers the institutionalization of one of these regimes to be dominant or preferred. The identification of new regimes, the correct or incorrect inclusion of different countries, the expansion of the regimes themselves to study other aspects of the policies or the debate on the very limitations of the categories used to systematize the different regimes have shaped the driving forces behind the study of the WS since the publication of this seminal work (Ferragina, Seeleib-Kaiser and Spreckelsen, 2014; Manow, 2017). After nearly three decades of changes and transformations, the comparative evidence points towards the continued existence and coherence of the worlds, regimes and families of countries in terms of welfare (Castles and Obinger, 2008). The worlds of welfare seem to still be "alive" in terms of validity and capacity to explain the "real world of welfare" (Ferragina, Seeleib-Kaiser and Spreckelsenm, 2014) and the different structures of the party systems (Manow, 2009 and 2015).

In the liberal or neoliberal regime or world, predominant in countries like Ireland or the United Kingdom, the main creative force lies in the tension between the capital needs and the mobilization of work, resulting from provisioning systems restricted by a selective and individualized expense (Hill, 1997). Its policies are subordinated to the rules of work ethics: public assistance is embarrassing and requires the prior verification by the state of the candidate's need. It is governed by strict and restrictive rules of access and exclusion. It is implemented through specific expenditure programs that are limited and discriminatory, with a subsidiary vision of the decommodification of rights, since the mission of the WS is not to make the individual independent, rather to promote the functioning of the market.

In the conservative, Catholic or Christian democratic regime, predominant in countries such as Germany, Austria and France, the main driving force is found in the combined influence of political Catholicism and the continued existence of the former authoritarian statalism. The result has been a medium-sized provisioning system in which the rights are linked to social status and membership in a specific social group. In the conservative world, expenditure is organized by groups, with the dominance of the family as the unit of provisioning, carefully limiting access to the system to individuals or non-traditional family units. The main mission of the 
conservative WS is to maintain the differences between groups and social and economic statuses. Its redistributive impact is minimal, although the state structure attempts to replace the market as the provider of social welfare (Pinch, 1997).

In the social democratic or universalist regime or world, predominant in countries like Denmark, Finland and Sweden, the driving force stems from the tension between the leftist parties in the government and the Christian parties in the opposition. The social democratic world offers a peculiar blend of liberalism and socialism, strengthening at the same time the capacities to maximize individual independence and freedom of choice, with expenditure programs of a universal nature whose primary mission is the decommodification of rights (Zijderveld, 1999). Expenditure is universal, because it seeks to promote equality from very high standards of provision, thus making it the provisioning system with the greatest volume. Rights are formulated in a comprehensive manner. Family costs and market transaction costs are socialized, because the main task of the WS is to ensure the emancipation of the individual as opposed to the family and market.

Beyond the three original worlds of Esping-Andersen, in Southern Europe, Spain, Greece, Italy and Portugal would form another regime with its own identity, which the most accredited authors (Moreno, 2005, 2009 and 2013; Ferrera, 1996; Sarasa, 1995) have referred to as "Mediterranean," as a fourth regime or world of WS. These are countries that have constructed their welfare models over time, combining elements of the social democratic regime and the conservative regime, marked by a delay in the modernization process, the persistence of authoritarian regimes, the weight of the Catholic church as a provider of social assistance and the central role of the family as a welfare distributor. The Mediterranean regime is set up as such with elements typical of a system based on income maintenance and group membership, along with elements typical of an almost universal coverage system.

Until the onset of the financial recession in 2007, the debate on the future and reform of the WS focused on the foundations of its policies, the efficiency of its results, the legitimacy of its decisions and the effectiveness of its interaction, in terms of expenditure, taxation and the creation or destruction of jobs as the result of the globalization process (Boix, 2001) or the European integration process (Korpi, 2003). Debated were the abuses and inefficiencies of its policies, the controversial redistributive and distributive results produced after decades of expenditure (Bradley, Huber, Moller, Nielsen and Stephens, 2003), and the progressively negative impact of globalization on the volumes of social expenditure in the name of efficiency (Busemeyer, 2009), or just the opposite, its positive impact, providing for an increase in expenditure to compensate "the losers of globalization" (Walter, 2010).

No specific offers for large cutbacks in programs or expenditure volumes were proposed or discussed (Esping-Andersen and Palier, 2010). This was undoubtedly due to the evidence that one of the most solid sources of political resistance of the WS to criticism lies in the electoral incentives created by the broad social and popular support for welfare policies (Pearson, 1998), systematically accredited by opinion studies in all European countries.

To reduce social expenditure, first it was crucial to convince the majority that 
it was indeed an expenditure, but not social. In fact, the neoliberal criticism of the WS has concentrated its efforts on questioning both the efficiency and the legitimacy of the expenditure decisions (Niskanen, 1971), mounting a powerful discourse in which social expenditure no longer responds to the needs of the "people," but rather to the private interests of "bureaucrats" and "politicians," who assign and manage it in a way that is increasingly more removed from the control and interests of citizens (Hemerijk, 2018). The intent of this criticism was to oust the idea of the WS from the hard-core of the collective identity as European democratic societies. The result has been that the WS has gradually lost ground and a base in our collective identity, to become something that always benefits others (Sharpf, 1999). In this account, the defense of private management does not merely represent a commitment to a superior model. It also becomes the path to returning the freedom and capacity for choice to individuals, as opposed to the threat of an authoritarian and confiscatory welfare state, held prisoner by revenue hunters and corporate or partisan interests (Hemerijck, 2018).

If we measure the impact of these criticisms in terms of the volume of expenditure on healthcare, education or social protection before the Great Recession, the first impression would be that the WS has resisted reasonably well the scourges and policies of austerity. But if we measure the impact inflicted on the very idea of welfare, understood as the "institutionalization of the governmental responsibility to maintain certain minimal national standards of welfare" (Mishra, 1990), the conclusion is quite different. The debate on the WS has fully encompassed efficiency, efficacy and the justice of the welfare policies and their distributive and redistributive effects.

Continuing with the typology of the welfare regimes, we can systematize in greater detail the different impacts caused by the policies of withdrawal or recalibration, implemented in response to the criticism that has been taking shape in public debate in Western societies with regard to the functioning and efficacy of their services and public bureaucracies (Pierson, 1991 and 2001). It can be stated that, in light of demographic and economic pressures, the globalizing changes and the de-industrialization or the consequences of the Great Recession and the debt crisis, countries have opted to either encourage individual solutions, modifying the incentives generated by the WS, or develop policies and programs aimed at aiding individual decisionmaking and bolstering equality of opportunities (Taylor-Gooby, 2011).

In the liberal regime or world, "liberal collectivism" has evolved into the "market society" (Grimshaw, 2015), following a path towards the recommodification of rights based on a practically unlimited faith in the market and a firm political commitment to the withdrawal of the state (Navarro, 1998). Governments are moving towards reducing the rights associated with citizenship, limited to covering the worst risks, and restricting even more profusely and stringently the conditions for eligibility (Hill, 1997; Grimshaw, 2015). In this “market society," public needs present an increasingly more residual concern, subordinate to the needs of the market and the economy. Social risks are increasingly more restrictively defined, and a shift is occurring towards more local systems of provisioning or those that 
operate in cooperation with the private sectors. In the liberal world, a "dual system" has been consolidated with one network of services for those who are within the market and compete in it and another welfare-oriented and providential network for those who are left outside.

In the conservative, Catholic or Christian democratic regime, a certain recalibration of rights has gradually come into being. Employment has better resisted in "coordinated capitalist" countries, this is Luxembourg, the Netherlands, Germany and Austria, which are the ones that have least reformed their labor markets in the direction of liberalization and have preserved their mechanisms of collective bargaining and their institutions of industrial relations (Degryse, Jepsen and Pochet, 2013). Even though there has been a "changing of the guard" and its appearance and forms have changed, an important and renewed corporatism remains (Jahn, 2016), also strengthening the weight of segmentation by social and corporate status in order to access these rights. The family maintains its central role and public intervention is limited to acting in response to its failures. The preference for public services remains, but the increasing provision of social services via the market is promoted, particularly volunteer associations and charities (Pinch, 1997). The passive focus on employment strategies has not changed substantially, but not enough to avoid interference in the market, such as to preserve the role of the head of the household. The primary risk lies in the fact that the financing of the system responds poorly in times of recession: more unemployment means less income, fewer resources and more demand. Hence, the evolution is towards a "dual system," where two "sub-worlds" of welfare coexist: a stable network of services and rights for those who have a stable professional career and another more fragile network for those who live with precarious employment.

The evolution of the social democratic regime has been marked by the acceptance of the superiority of the market in achieving certain results, but always preserving a crucial role for powerful state intervention (Green-Pedersen, Van Kersbergen and Hemerijck, 2001). Cost containment has gradually been prioritized. Even so, a high level of commitment remains to comprehensive risk coverage and generous levels of benefits (Nordlund, 2000). Even though the social democratic world formally maintains its universal character and rights accompany the individual-citizen, aid linked to the need and the attitude of the beneficiaries has been gaining ground (Nordlund, 2000).

Countries belonging to the social democratic regime conserve a high degree of decommodification of rights but have abandoned the policies of full employment and expansion of social services, and like in the rest of Europe, their policies have been "Americanized" (Zijderveld, 1999). In fact, even though the labor market has barely been reformed in the countries belonging to the conservative and social democratic regimes during the recession, cutbacks in social policies promoted by the European institutions affect them in a way similar to the rest of the Member States (Degryse, Jepsen and Pochet, 2013). The main risk lies in the high level of taxation required to maintain them and the threat the increasing mobility of money represents for their financing (Scharpf, 1991 and 1999). This regime has evolved 
towards the weakening of the state monopoly, bolstering combined services with an increasing weight of private management models and initiatives. In this regime, there is no dualization of the network, rather dualization of the forms of provisioning, according to which the same network of services takes on two different forms of provisioning: through public bureaucracies and private providers.

In the area of the Mediterranean regime, in Southern Europe, which shares the so-called "middle road" to welfare (Moreno, 2005 and 2009; Moreno and Sarasa, 2012), the road to WS reform has combined in some disorganized fashion elements of the revisions and transformations of the "conservative" regime in terms of income maintenance and group membership and those of the "social democratic" regime, in terms of the universalizing resolve of the system. Its evolution started in the 1980s and 1990s and has been focused on freezing or taking back control over the processes of universalization of healthcare and education, reinforcing the link between need accreditation and access to programs and the commitment to methods of provisioning that prioritize market formulas or volunteer associations and charities. During this time, the Mediterranean regime has moved towards a "double dual system" with regard to both the service proposals (universal and selective) and the forms of provision (Losada, 2013 and 2015). The combination of welfare services based on a universal conception and services based on a selective mode of operation has been gaining weight. The combination of formulas of public and private provisioning has also increased.

Table 1 synthesizes the main patterns of reform in the welfare worlds and helps us understand how it has affected their distinctive elements. As can be seen, more than radical transformations or reductions in the volume of welfare programs, the main changes have affected the philosophy and categories that defined them. The spending programs remain relatively stable in terms of volume. It is the ideas, visions and missions that define them that have changed and are transformed.

Table 1: Four welfare regimes revisited

\begin{tabular}{|l|l|l|l|l|}
\hline & \multicolumn{1}{|c|}{ Liberal } & \multicolumn{1}{|c|}{ Conservative } & \multicolumn{1}{c|}{$\begin{array}{c}\text { Social } \\
\text { democratic }\end{array}$} & \multicolumn{1}{|c|}{ Mediterranean } \\
\hline Role of the family & Marginal & Central & Marginal & Central \\
\hline Role of the market & Central & Subsidiary & Subsidiary & Subsidiary \\
\hline Role of the state & Marginal & Subsidiary & Central & Central \\
\hline $\begin{array}{l}\text { Dominant mode } \\
\text { of solidarity }\end{array}$ & Individual & $\begin{array}{l}\text { Corporatism } \\
\text { Statism }\end{array}$ & Quasi-universal & Combination \\
\hline $\begin{array}{l}\text { Dominant distributor } \\
\text { of solidarity }\end{array}$ & Market & Family & State & $\begin{array}{l}\text { State } \\
\text { Family }\end{array}$ \\
\hline Amounts & Minimal & $\begin{array}{l}\text { High } \\
\text { (for heads of } \\
\text { household) }\end{array}$ & High & Low \\
\hline Financing & $\begin{array}{l}\text { Individual } \\
\text { contributions } \\
\text { Taxes }\end{array}$ & $\begin{array}{l}\text { Social } \\
\text { contributions }\end{array}$ & Taxes & $\begin{array}{l}\text { Taxes } \\
\text { Social contributions }\end{array}$ \\
\hline
\end{tabular}

Source: Authors' own work. 
The Great Recession has had an effect on the evolution of the different welfare regimes found on the European continent and their increasing hybridization, but the very process of European construction has also had an important influence. The increasing coordination of economic and budgetary policies, through tools such as the European Semester, have favored the dynamics of standardization and homogenization of social policies on the continent, especially in those countries that were forced to turn to the EU for assistance as the result of their difficulties in obtaining financing on the market (Costamagna, 2013).

The extension of policies marked by the priority of budgetary balance over the social dimension, along with a conception of social policies subordinated to economic growth, have shaped the base of the reform trends in welfare policies set by European institutions (Costamagna, 2013). They do so as part of a strategy in response to the economic recession, but also according to a certain vision of how the monetary and economic union must work: prioritization and centralization of the monetary policy and decentralization and flexibilization of the social model (Degryse, Jepsen and Pochet, 2013).

The influence on the welfare reforms has been accentuated by the context of vulnerability of the Monetary Union during the sovereign debt crisis, especially in those countries with the greatest domestic vulnerability (De la Porte and Natali, 2014). The EU has provided a strategy of reforms supported by a more residual conception of the WS, instrumentalized by means of increasingly more selective programs, and a colonization of social policies by economic policies, even to the point of turning the "system of strengthened economic governance" into an instrument to change the bases of the European social model (Degryse, Jepsen and Pochet, 2013).

This strategy has been used tacitly by national politicians to promote their own agenda of reforms, both prior to and concurrently with said changes (De la Porte and Pochet, 2012). This European imbalance in favor of economic objectives and to the detriment of social objectives only begins to show signs of gradual correction in favor of social objectives with the start of the recovery in 2012 (Costamagna, 2013). How far the scope of this correction can reach is undoubtedly one of the greatest unknowns that must be determined in the future during the process of European construction. Until 2013, the different welfare regimes have implemented different policies in light of the Great Recession, albeit based on a common strategy generated by the homogenizing effect of the response induced by the EU, subordinating welfare policies to economic policy and a more residual conception of the WS.

\section{PREFERENCES ON SOCIAL SPENDING OF THE NATIONAL PARLIAMENTS OF THE EU-15. POLITICS}

Cutbacks in welfare policies and social spending programs are not only explained in terms of globalization and post-industrial development processes, or by the very process of European construction itself. Abundant empirical evidence con- 
firms that the likelihood of these cutbacks increases according to the partisan composition and ideological orientation of the governments: the risk of greater cutbacks decreases with left-wing governments and increases with conservative or centrist governments and, somewhere in the middle, in those with religious leanings (Korpi and Palme, 2003). In other words, the political preferences matter; they explain the dynamics of growth and reform in the different welfare regimes coexisting in Europe.

There is a surprising "isomorphism" (Manow, 2009) between the European worlds of welfare and the different party systems as the result of both electoral rules and the different coalitions of government. Countries with majority electoral systems and predominantly conservative governments present liberal and residual models of welfare. Countries with proportional electoral systems present two varieties: where executives of the "red-green" coalition predominate (social democrats and agrarian parties), the Nordic welfare model is supported, and where the "redblack" coalition governments predominate (social democrats and Christian democrats), a continental welfare model prevails (Manow, 2009), while the break on the left between the social democrats and the communists would be characteristic of the Mediterranean welfare model (Manow, 2017).

The analysis of the electoral manifestos of different parties in Europe between 1996 and 2013 now lets us see the point to which these correlations have been affected in terms of responses to the economic expansion generated by the implementation of the euro (1999) and the subsequent Great Recession (2007).

In a first analysis of proposals on social spending aggregated from a continental perspective (Figure 1), we can see how, during the period prior to the entry of the euro and the period of economic expansion that followed it, there was constant, sustained growth of stances on social expenditure in the manifestos of the main European parties, reaching the maximum level precisely in 2007, the year the financial recession began. This marks the start of a downward trend that maintains the manifesto proposals above, but close to the levels recorded in the mid-1990s, when economic growth began to overshadow the fiscal adjustment policies prior to the euro.

Proposals for social spending cutbacks or social retrenchment, in turn, make barely noticeable and consistently marginal advances among these same parties and during these same periods. The Great Recession marks the moment when a clear change in trends occurred. Proposals for additional social spending policies dwindle, while the slight upward trend in contractionary proposals is consolidated, although consistently without abandoning the periphery of the manifestos of the large parties. The start of the economic recovery does not substantially change these trends marked by a sustained decrease in partisan proposals for greater social spending and a slow, but consistent increase, still from the periphery of the manifestos, of partisan proposals for less social spending, until settling slightly above the levels set in the mid-1990s. 
Figure 1: Parliamentary support for social spending and social retrenchment in the EU-15 (1996-2013)

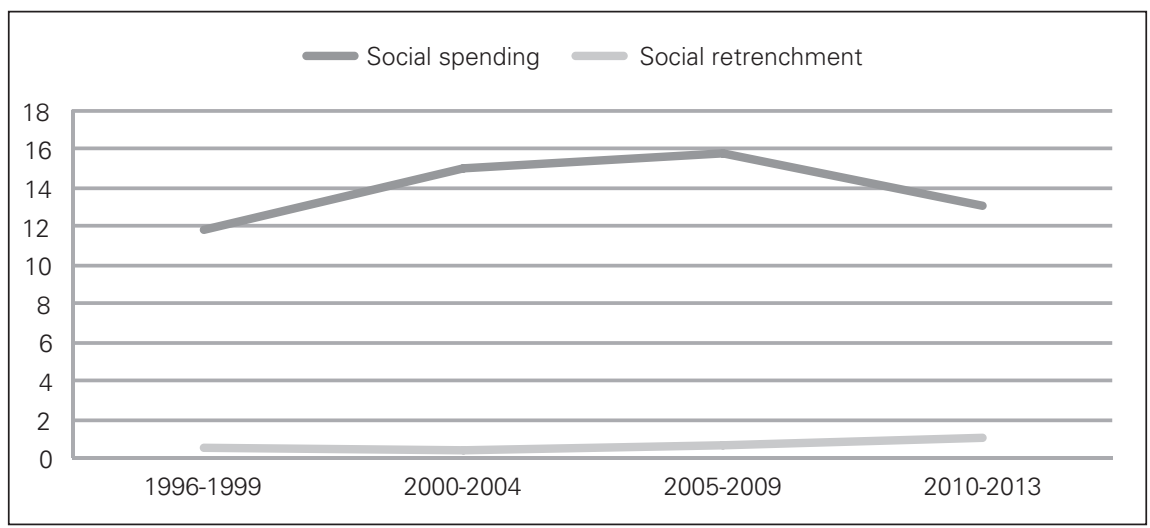

Source: Manifesto Project's dataset, version 2017b. Social spending: $(504+506)-(505+507)$, weighted by the number of seats. Social retrenchment: $(505+507)$, also weighted by the number of seats.

Observed from a continental perspective, in an aggregated manner, social spending (Figure 2) and welfare policy proposals seem to have been aimed in the same direction as that marked by the EU through its policies, as set out above: during the economic boom, the proposals expanded and the more restrictive programs remained on the margins of the partisan competence, while during the Great Recession, additional welfare or new social spending proposals decreased in the party manifestos and more restrictive manifestos gained ground; neither trend seems to have changed, even with the start of the economic recovery.

However, when we disaggregate the data, it is seen that while there are no apparent differences in terms of the direction of the trends, the intensity and rhythm of change in each welfare regime and each country can be clearly seen. Partisan proposals are generally aimed in the same direction, aligned with the vision of subjecting social objectives to economic ones, promoted by the EU and accelerated by the Great Recession. But they march at different speeds, depending on the dominant welfare regime in each country, and each regime develops at its own speed.

If we compare the evolution of the expansive proposals, grouping them by welfare regime, we notice significant differences. The partisan proposals for greater social spending in the countries with liberal, social democratic and Mediterranean regimes show similar curves and evolutions in their profiles, but differences in terms of their intensity. Accordingly, in countries of the liberal world, partisan proposals on social expenditure greatly increased during the years of the expansion of the euro, only to later be those countries where they most quickly decreased in volume following the crash of the financial recession, until returning to the levels of the mid-1990s.

Countries of the social democratic regime are those where partisan social spending proposals expand the most during the years of post-euro growth, going on to experience a sharp contraction with the onset of the Great Recession. This 
was not even reversed with the start of the economic recovery; even so, the partisan proposals for additional spending maintained their expansion at levels clearly greater than those recorded before the introduction of the euro. The evolution of the Mediterranean regime, in turn, replicates the same trends, although in a gentler and more reduced manner, with a moderate increase in the partisan social expenditure proposals during the years of economic expansion and also a gentler contraction during the Great Recession; in fact, social spending policy proposals in the Mediterranean regime reveal a curve that more precisely fits the curve of the mean of the EU-15, and then finally shows levels equal to those recorded in the mid1990s, when the southern countries were still in the midst of making fiscal efforts to meet the conditions to access the single currency.

On the other hand, in the countries in the conservative world, almost the opposite occurs as in the other regimes: the partisan proposals to expand social expenditure increase during the years of fiscal adjustment prior to the implementation of the euro, decline during the years of the economic boom and recover and start to increase again with the emergence of the economic recession, constituting the only proposals to increase even more with the start of the economic recovery, managing to remain at levels superior to those recorded prior to the entry of the euro. This dynamic does not seem to be entirely foreign to the previously mentioned persistence of economic and social corporatism in these countries.

Seen in perspective, it can be observed that the social democratic and conservative regimes have contemplated how their partisan proposals for greater welfare and more social spending have increased and remain above the average for the EU, while the liberal and Mediterranean regimes have distanced themselves from both, and have returned to the levels prior to the introduction of the euro and the Great Recession, in net terms below the mean.

Figure 2: Position on social spending in the national parliaments of the EU-15

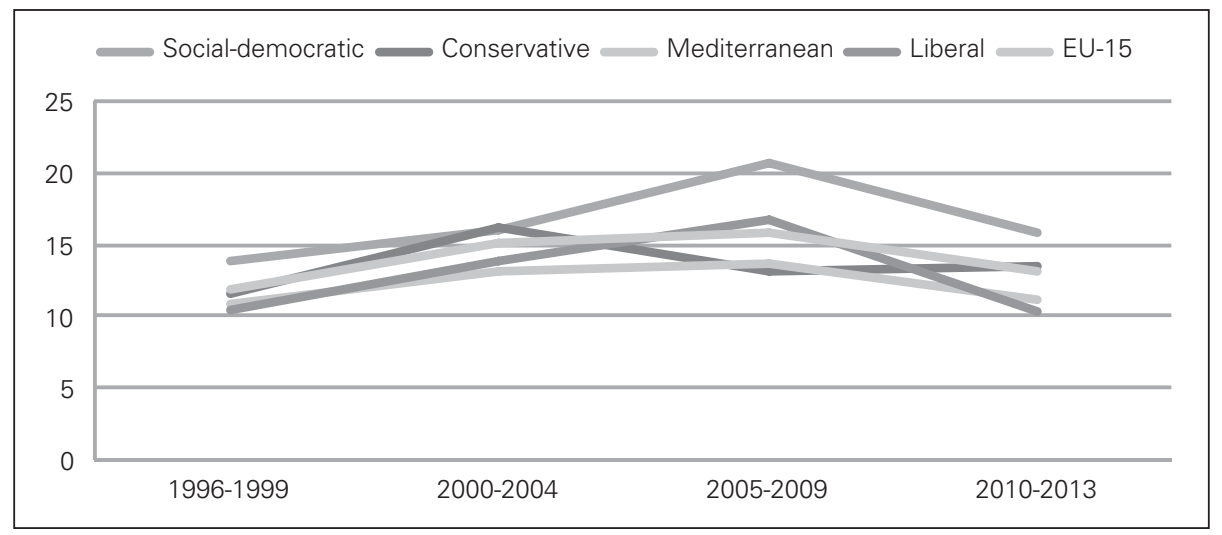

Source: Manifesto Project's dataset, version 2017b. Position of parliament on social spending: (504+506) $(505+507)$, weighted by the number of seats. 
If we also disaggregate the analysis of the partisan proposals for less social spending by regime (Figure 3), we observe how in the countries with the social democratic regime, the more restrictive proposals accelerate during the years prior to the Great Recession and are consolidated during the recession, while in the countries belonging to the liberal and conservative regime, the progression of the most restrictive reform proposals for their social spending and their welfare policies accelerate after the onset of the economic recession. The countries of the Mediterranean regime once again represent the difference, as they are the ones where the least progress is made by partisan proposals for greater cutbacks as part of their party manifestos. The difference between the proposals from the countries in the conservative world and the rest is recorded more clearly during the expansive years of the euro: the party manifestos in countries with a conservative regime are the only ones that reduce their reform and cutback proposals during the years of the economic boom, only to noticeably increase with the arrival of the economic recovery. In the rest of the regimes, the arrival of the euro marks the start of sustained, constant increase in partisan proposals for less social expenditure.

Figure 3: Support for social retrenchment in the national parliaments of the EU-15

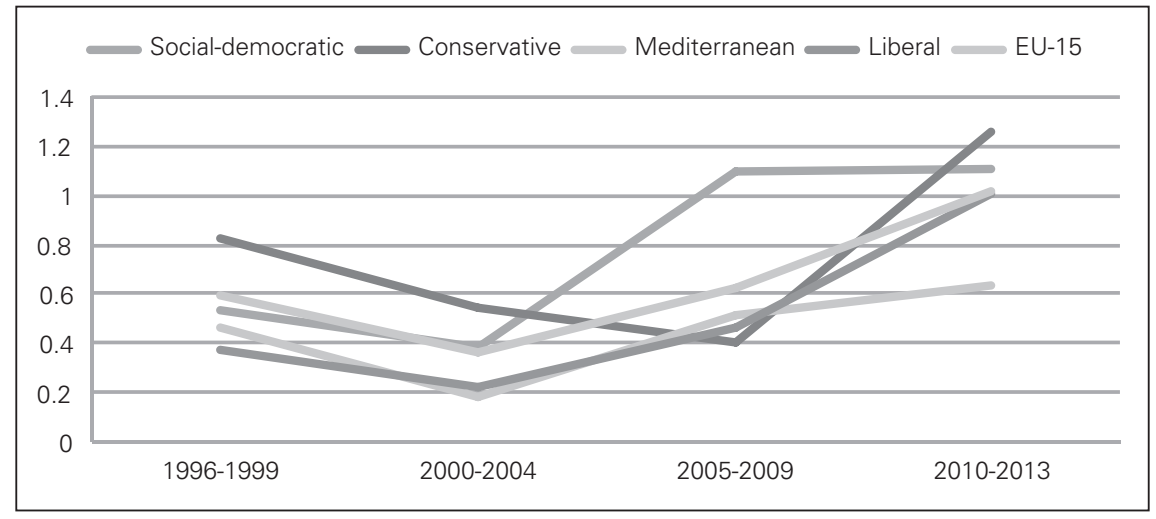

Source: Manifesto Project's dataset, version 2017b. Party statements in favor of social retrenchment $(505+507)$, weighted by the number of seats.

The comparison of the manifesto proposals for more or less social spending among the countries in the different welfare regimes makes it possible to confirm that "welfare politics" also reproduces the homogenizing trends promoted by Europe and indicated above in the analysis of the "welfare policies." The continental regime marks the exception in a convergent trend among the remaining regimes. Promoted by the European construction process, it moves towards a growing subordination of social policies to needs, rhythms and pressing needs of economic policies. In addition to the already mentioned standardization and homogenization of social policies on the continent, there is also increasing standardization and homogenization of policy proposals, which are increasingly dominated by a residual 
conception of the WS, discriminatory and selective programs and the colonization of social policies by economic policies.

The analysis of the countries in each world also shed interesting light on the subtleties found in the different political proposals generated in each. In the countries normally affiliated with the conservative world (Figure 4), it can be observed how, during the years prior to the implementation of the euro, with harsh fiscal adjustment policies imposed to harmonize national economies, we see the moment of maximum expansion in partisan proposals for more social spending in the manifestos of the main parties. The years prior to the onset of the Great Recession experienced a contraction in manifesto proposals concerning welfare and social expenditure, which resists the toughest years of the recession and seems to start to show signs of recovery as the economic recovery begins, also showing a clearly convergent trend towards similar volumes of proposals. The exception is seen in France, where the main parties maintain slightly expansive proposals during the years prior to the recession, which paradoxically begin to revise with the start of the economic recovery. Welfare policy and social expenditure proposals in countries belonging to the conservative regime, marked by their resistant economic and social corporatism, seem more to anticipate the economic cycles than respond to them. The expansive cycles are taken advantage of to revise social policy proposals, under good growth and employment conditions, while the contractive cycles show an entrenchment of welfare proposals to compensate for the consequences of the recession. As seen when examining the evolution of policies, in the conservative world, social expenditure proposals seem to maintain their own dynamics and even increase in terms of autonomy in response to the cycles and pressing needs of the economic policies.

Figure 4: Parliamentary preferences on social spending in the continental welfare regime

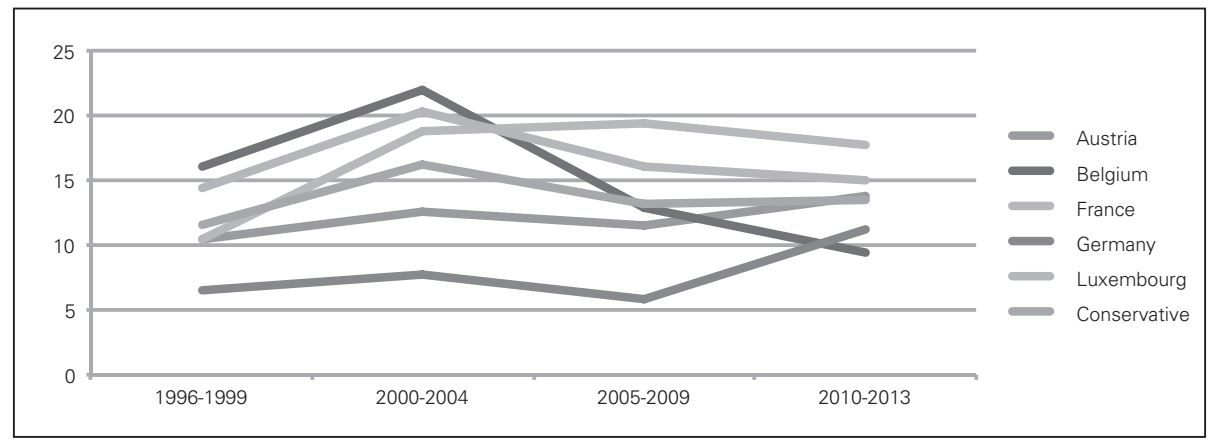

Source: Manifesto Project's dataset, version 2017b. Position of parliament on social spending: $(504+506)-$ $(505+507)$, weighted by the number of seats. 
It is in the social democratic world (Figure 5) where the greatest divergences are recorded among the manifesto proposals of the parties in the different countries, although a common trend is confirmed to accompany economic cycles, just the opposite of what occurs in the conservative world. Boom periods mark sequences of expansion in partisan proposals for greater social spending, while the response during the recession is one of overwhelming contraction of social expenditure proposals. This is a pattern that the 2007 recession noticeably accelerates, and it has not even been halted by the start of the recovery. As occurred with the policies, it seems clear that in the social democratic world, social spending and welfare policy proposals have become increasingly dependent on rhythms and pressing needs of economic policies. Only Sweden is an exception from this general downward converging trend, which is even anticipated in the case of Finland, marking a recovery of the partisan proposals for greater welfare starting in 2010 , as the economic recovery approaches.

Figure 5: Parliamentary preferences on social spending in the social-democratic welfare regime

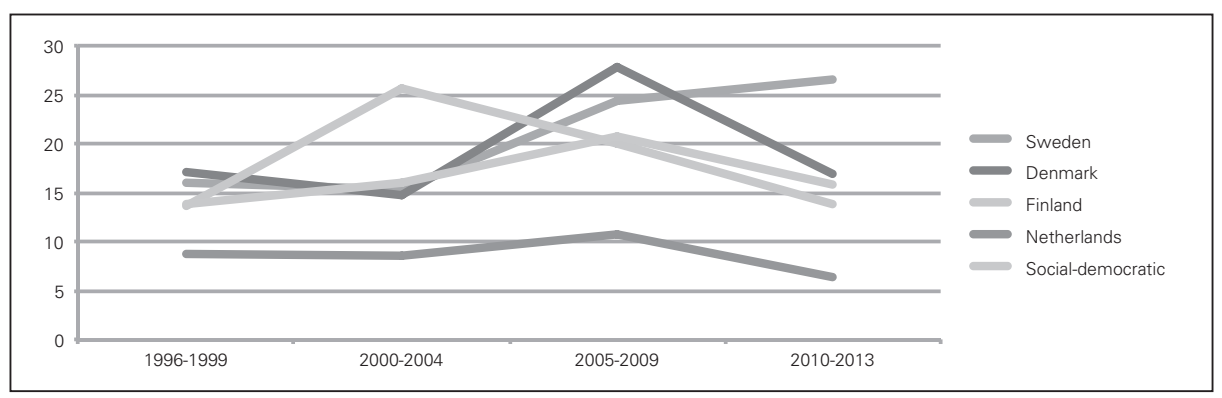

Source: Manifesto Project's dataset, version 2017b. Position of parliament on social spending: $(504+506)-$ $(505+507)$, weighted by the number of seats.

The curves for the manifesto social spending proposals from the political parties in the liberal regime (Figure 6) contradict to a certain extent the fairly common perception that it is precisely in these welfare states where the most cutbacks and reforms have taken place since the 1980s, and where critical discourse is most reflected in political debate. On the contrary, the proposals by the main political parties have been strongly expansive prior to the onset of the financial recession in 2007, when the trend unequivocally reverses itself, as occurs in the social democratic regime. Not even the start of the recovery has an impact on proposals where the thesis has clearly been imposed that social policies must be subordinated to economic policies. 
Figure 6: Parliamentary preferences on social spending in the liberal welfare regime

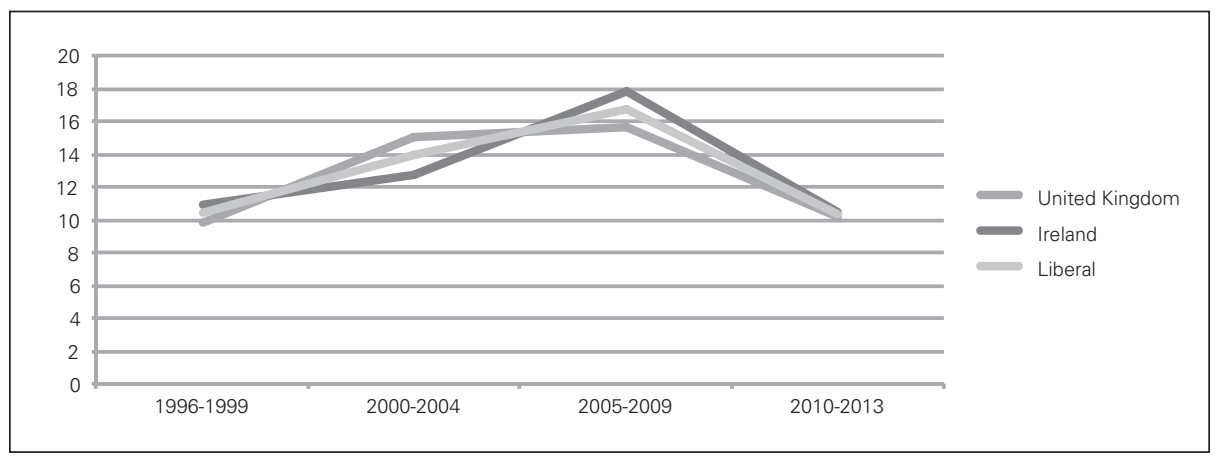

Source: Manifesto Project's dataset, version 2017b. Position of parliament on social spending: $(504+506)-$ $(505+507)$, weighted by the number of seats.

The countries in the Mediterranean regime (Figure 7) show curves for social spending partisan proposals that, hardly surprising, somewhat suggest the curve typical of the liberal regime, although to a lesser scale and with a lower volume, in line with the smaller size of their WS, and with weaker trends, as corresponds to the degree of economic and social corporatism inherited from their authoritarian past. With the notable exception of Greece, where trends become more pronounced following the rescue of their economy, the curve for the partisan proposals for greater welfare expands during the boom period and contracts slightly during the years of the economic recession, which does not prevent the partisan proposals for more welfare from being clearly greater following the recession as compared to before the euro.

Figure 7: Parliamentary preferences on social spending in the Mediterranean welfare regime

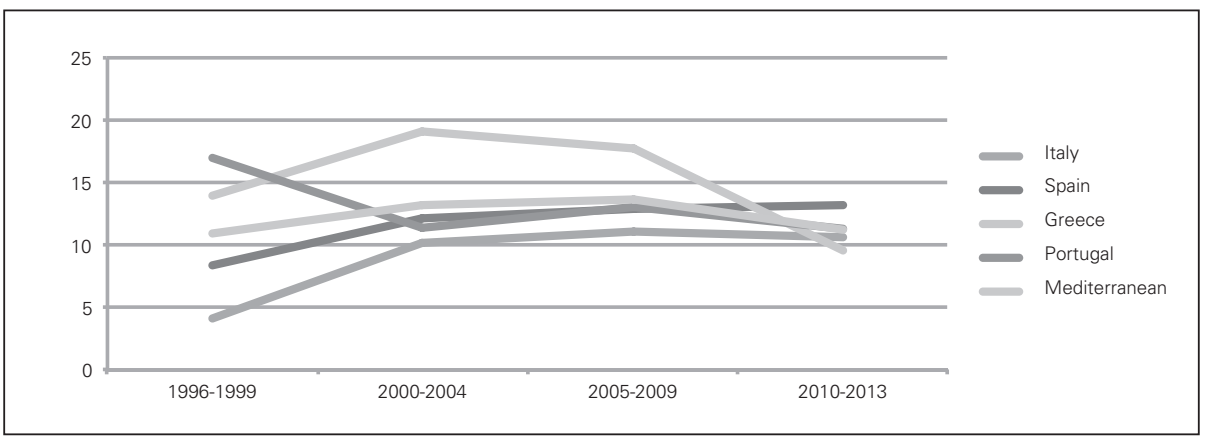

Source: Manifesto Project's dataset, version 2017b. Position of parliament on social spending: $(504+506)-$ $(505+507)$, weighted by the number of seats.

It should also be pointed out that, upon emerging from the Great Recession, a trend is observed towards convergence among parliamentary positions in favor of expanding social spending within each of the regimes. This implies, for example, a decrease in support for social expenditures in Greece and Portugal, but an increase 
in Spain and Italy, and a rapid increase in the intensity of preference for social spending in Germany, where at the start of the period, this matter was less present in the party manifestos (Figures 8 and 9).

Figure 8: Variation in the parliamentary preferences regarding social spending in the EU-15 between 1996 and 2013

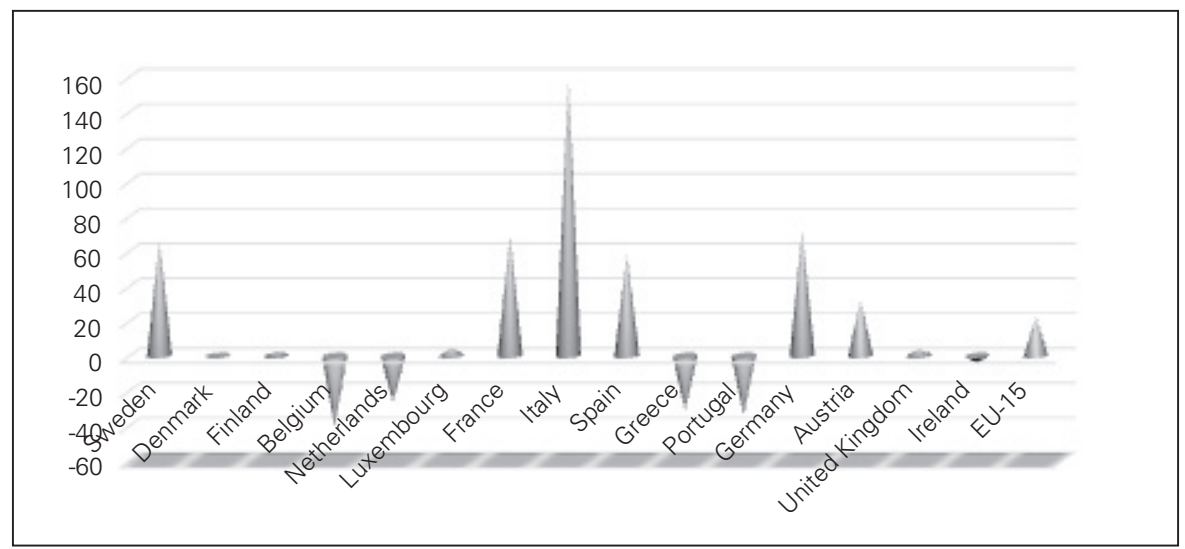

Source: Manifesto Project's dataset, version 2017b. Position of parliament on social spending: (504+506) $(505+507)$, weighted by the number of seats.

Figure 9: Variation in the parliamentary preferences regarding social spending in the EU-15 during the Great Recession

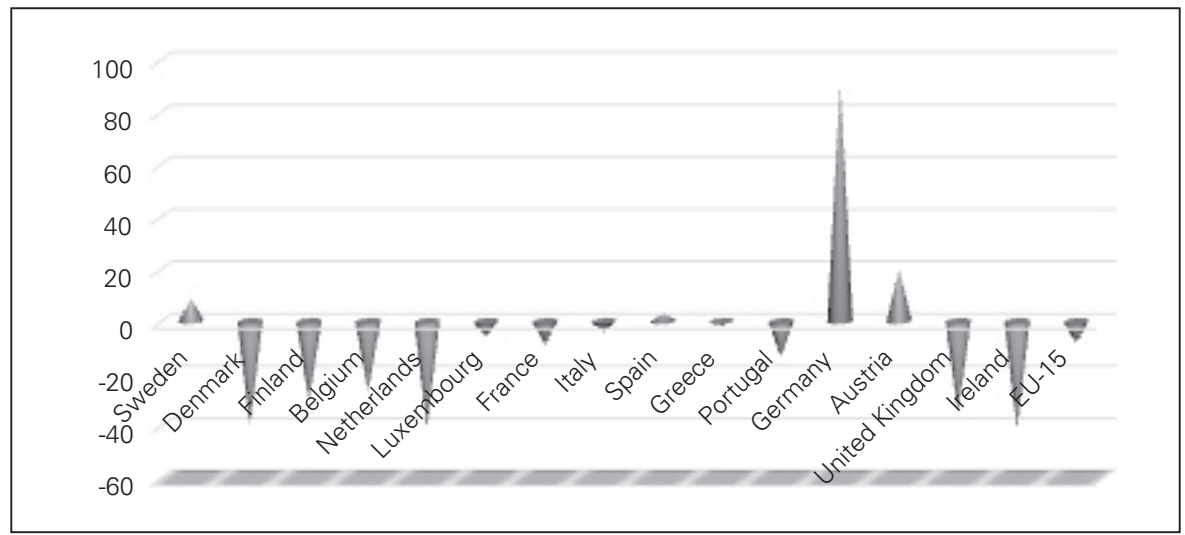

Source: Manifesto Project's dataset, version 2017b. Position of parliament on social spending: $(504+506)-$ $(505+507)$, weighted by the number of seats. 


\section{CONCLUSIONS: THE ENDURING RELEVANCE OF THE FOUR EUROPEAN WORLDS OF WELFARE}

The analysis of the evolution and changes recorded in "welfare policies" and "welfare politics" in Western Europe during the years surrounding the introduction of the euro and the Great Recession has allowed us to test the validity of our working hypothesis. An increasingly homogeneous conception is detected in which social policies are subordinate to economic policies, more sharply so with the emergence of the Great Recession, but the different welfare regimes have clearly had an influence on social spending and welfare policies, developing different strategies in response to problems of sustainability and the need for reform of the WS.

Accordingly, few changes are seen in the basic elements of the model in the conservative regime, based on economic and social corporatism, although changes in the provisioning to different groups have occurred: the public provisioning network remains unscathed for those who remain in the labor market and is weaker for those who are outside it. In the liberal world, this dualization of services is consolidated with a more stable network that is better equipped for those who can compete in the market and another welfare-oriented and providential network for those who cannot. In the social democratic regime, there is evidence of an increasing public-private dualization of the forms of provision by a system that maintains its public and universal character. In the Mediterranean world, the evolution is confirmed towards a dual offering of universal and selective services and dual methods of provision.

Likewise, the different welfare regimes have induced different dynamics and rhythms in the evolution of welfare manifestos of the main parties, and with this, in the preferences shown in the national parliaments. In terms of volume, two overall converging trends are observed: the conservative and social democratic regimes come together in the upper band of proposals made, while the liberal and Mediterranean regimes do so in the lower band.

In the conservative world, the manifesto proposals regarding social spending tend to anticipate the economic cycles: they contract and are revised in expansive cycles, with increasing numbers of reform proposals during boom periods, and expand as compensation during periods of recession. The liberal and social democratic regimes, in turn, inspire strong expansions and contractions in the partisan proposals for greater social expenditure and welfare policies, accompanying the economic cycles. The downward shift in manifesto proposals proves to be especially striking in both regimes during the Great Recession. Finally, in the Mediterranean world, we see both the significantly lower volume of partisan social spending proposals as compared to the other regimes, as well as the variability of the partisan proposals for more social expenditure according to economic cycles.

In short, the analysis of the position regarding the volume of social spending of national parliaments in the EU-15 during the 1996-2013 period has enabled us to confirm the homogenizing force accompanying the reforms of the social policies promoted by the EU, which is more pronounced within each regime as compared 
to among regimes. The resistance of the concept of welfare regime should be stressed and with it the sometimes-surprising capacity of influence of the institutional factors on the design of expenditure policies, not only in globalization, but also in a context of recession.

\section{REFERENCES}

Alonso, S., Volkens, A. and Gómez, B. (2012) Análisis de contenido de textos políticos. Un enfoque cuantitativo, Madrid, CIS (Colección Cuadernos Metodológicos, 47).

Ares, C. and Volkens, A. (2017) "Representación, estructura de la competencia e ideología de los partidos políticos: el empleo de los indicadores de MARPOR en América Latina”, Revista Latinoamericana de Política Comparada, 12: 9-28.

Ares, C. and Losada, A. (2020) "Political Parties' Preferences about the Volume of Social Spending and its Distribution between Programs and Age Groups: a Comparative Study of France, Spain and the UK", Cuadernos de Gobierno y Administración Pública, 7 (2): 85-98.

Bradley, D. Huber, E. Moller, S. Nielsen, F. and Stephens, J. (2003) "Distribution and Redistribution in Post Industrial Democracies", World Politics, 55 (January 2003): 193-228.

Busemeyer, M. R. (2009) "From myth to reality: Globalisation and public spending in OECD countries revisited", European Journal of Political Research, 48: 455-482.

Boix C. (2001) "Partisan governments, the international economy and macroeconomic policies in advanced nations, 1960-93”, World Politics, 53: 38-73.

Castles, F. G. and Obinger, H. (2008) "Worlds, families, regimes: country clusters in European an OECD area public policy”, West European Politics, 31 (1-2): 321-344.

Costamagna, F. (2013) "The European semester in action; strengthening economic policy coordination while weakening the social dimension?", Centro Einaudi, Working paper-LPF 5.

Cochrane, A. and Clarke, J. (eds) (1993) Comparing Welfare States: Britain in International Context, London, Sage.

Clarke, J. and Newman, J. (1999) The Managerial State, London, Sage.

De la Porte, C. and Pochet, P. H. (2012) "Why and how (still) study the Open Method of Co-ordination (OMC)?", Journal of European Social Policy, 22 (3): 336-349.

De la Porte, C. and Natali, D. (2014) "Altered Europeanization of pension reform in the context of the great recession: Denmark and Italy compared”, West European Politics, 37 (4): 732-749.

Degryse, C., Jepsen, M. and Pochet, P. H. (2013) The Euro crisis and its impact on national and European social policies, European Trade Union Institute. Working paper 5.

Esping-Andersen, G. (1990) The Three Worlds of Welfare Capitalism, Cambridge, Polity Press and Princeton, Princeton University Press.

Esping-Andersen, G. (1999) The Social Foundations of Postindustrial Economies, Oxford, Oxford University Press.

Esping-Andersen, G. and Palier, B. (2010) Los tres grandes retos del estado del bienestar, Barcelona, Ariel.

Ferragina, E., Seeleib-Kaiser, M. and Sprekelsen, T. (2014) “The Four Worlds of 'Welfare Reality' - Social Risks and Outcomes in Europe", Social Policy \& Society, 14 (2): 287-307.

Ferrera, M. (1996) "The 'southern model' of welfare in social Europe", Journal of European Social Policy, 6 (1): 17-37.

Grimshaw, D. (2015) "Britain's social model: rapid descent from "liberal collectivism" to a "market society", in The European social model in crisis: Is Europe losing its soul? Chapter 11, Elgar online.

Goerres, A. (2007) "Can We Reform the Welfare State in Times of 'Grey' Majorities? The Myth of an Electoral Opposition between Younger and Older Voters in Germany”, Max Planck Institute for the Study of Societies, Working Paper 5. 
Green-Pedersen, C., Van Kersbergen, K. and Hemerijck, A. (2001) "Neo-liberalism, the third wave or what? Recent social democratic welfare policies in Denmark and the Netherlands", Journal of European Social Policy, 8 (2): 307-325.

Hemerijck, A. (2018) "Social spending as a policy paradigm", Journal of European Public Policy, 25 (6): 810-827.

Jahn, D. (2016) "Changing of the guard: trends in corporatist arrangements in 42 highly industrialized societies from 1960 to 2010”, Socio-Economic Review, 14 (1): 47-71.

Korpi, W. (2003) "Welfare State Regress in Western Europe: Politics, Institutions, Globalization, and Europeanization”, Annual Review of Sociology, 29: 589-609.

Korpi, W. and Palme, J. (2003) "New Politics and Class Politics in the Context of Austerity and Globalization: Welfare State Regress in 18 Countries, 1975-95”, The American Political Science Review, 97 (3): 425-446.

Losada, A. (2013) Piratas de lo público, Barcelona, Deusto.

Losada, A. (2015) Los Ricos vamos ganando, Barcelona, Deusto.

Lynch, J. (2015) "Age Politics and Pension Systems Development and Reform”, in C. Torp (ed) Challenges of Aging. Pensions, Retirement and Generational Justice (49-60), Basingstoke, Palgrave.

Manow, P. H. (2009) "Electoral rules, class coalitions and welfare state regimes, or how to explain Esping-Andersen with Stein Rokkan”, Socio-Economic Review, 7: 101-121.

Manow, P. H. (2017) "Workers, Farmers and Catholicism: a History of political class coalitions and the South-European Welfare State Regime”, RDRST, 3 (1): 8-36.

McKay, J. (1995) The Welfare State: No Mercy for the Middle Class, Liberty Books.

Merz, N., Regel, S. and Lewandowski, J. (2016) "The Manifesto Corpus: A new resource for research on political parties and quantitative text analysis", Research and Politics, 2: 1-8.

Mishra, R. (1990) The Welfare State in Capitalist Society, Hemel Hempstead, Harvester Wheatsheaf.

Moreno L. (2005) “La vía media española del régimen del bienestar mediterráneo". Unidad de Políticas Comparadas. Documento de Trabajo 99-05, Madrid, CSIC.

Moreno L. (ed.) (2009) Reformas de las políticas de bienestar en España, Madrid, Siglo XXI.

Moreno, L. (2013) La Europa asocial, Barcelona, Península.

Moreno, L. and Sarasa, S. (coords) (1995) El Estado del Bienestar en la Europa del Sur, Madrid, CSIC.

Moreno, L. and Sarasa, S. (2012) “Génesis y desarrollo del Estado del Bienestar en España”. Instituto de Estudios Sociales Avanzados Documento de Trabajo 92-13.

Navarro, V. (1998) Neoliberalismo y Estado del Bienestar, Barcelona, Ariel.

Nordlund, A. (2000) "Social policy in harsh times. Social security development in Denmark, Finland, Norway and Sweden during the 1980s and 1990s", International Journal of Social Welfare, 9: $31-42$.

Niskanen, W. (1971) Bureaucracy and Representative Government, Atherton, Aldine.

Pierson, C. (1991) Beyond the Welfare State? Cambridge, Polity Press.

Pierson, P (1998) "Irresistible forces, immovable objects: post-industrial welfare states confront permanent austerity”, Journal of European Public Policy, 5 (4): 539-560.

Pierson, P (2001) "Coping with permanent austerity: welfare state restructuring in affluent democracies", in P. Pierson (ed) The New Politics of the Welfare State, 411-55. Oxford, Oxford University Press.

Pinch, S. (1997) Worlds of Welfare. Understanding the Changing Geographies of Social Welfare Provision, London and New York, Routledge.

Scharpf, F. (1991) Crisis and Choice in European Social Democracy, Ithaca, New York, Cornell University Press.

Scharpf, F. (1999) Governing in Europe, Effective and Democratic? Oxford, Oxford University Press.

Scharpf, F. (1999) Socialdemocracia y crisis económica en Europa, Valencia, Edicions Alfons el Magnànim.

Schulz, J. H. and Binstock, R. H. (2006) Aging Nations: The Economics and Politics of Growing Older in America, Westport, Praeger. 
Taylor-Gooby, P. (2011) "Security, equality and opportunity: attitudes and the sustainability of social protection", Journal of European Social Policy, 19 (5): 150-14.

Titmuss, R. M. (1958) Essays on the Welfare State, London, Allen \& Unwin.

Volkens, A., Bara, J., Budge, I., McDonald, M. and Klingemann, H.-D. (eds) (2013) Mapping Policy Preferences from Texts III. Statistical Solutions for Manifesto Analysts, Oxford, Oxford University Press.

Volkens, A., Lehmann, P., Matthieß, T., Merz, N. Regel, S. and Weßels, B. (2017) The Manifesto Data Collection. Manifesto Project (MRG/CMP/MARPOR). Version 2017b. Berlin: WZB. https://doi. org/10.25522/manifesto.mpds.2017b.

Walter, S. (2010) "Globalization and the Welfare State: Testing the Microfoundations of the Compensation Hypothesis”, International Studies Quarterly, 54: 403-426.

Zijderveld, C. A. (1999) The Waning of the Welfare State: The end of Comprehensive State, New Jersey, Transaction Publishers. 